\title{
СИМБИОЗА НА ТЕОРИЈАТА И КРЕАТИВНОСТА
}

\section{(„Како си ми?“ - студентска филолошка конференција 2017,}

\author{
В. Блажевска, М. Величковска, В. Диздаревиќ, С. Грујоска, М.
}

Ефремов, Скопје, Филолошки факултет „Блаже Конески“, 2018)

\section{SYMBIOSIS OF THEORY AND CREATIVITY \\ (How are you? - philological student conference 2017, V. Blaževska, M. Veličkovska, V. Dizadarević, S. Grujoska, M. Efremov, Skopje, Blaže Koneski Faculty of Philology, 2018)}

Лидија Капушевска-Дракулевска

Универзитет „Св. Кирил и Методиј“, Скопје

l.drakulevska@flf.ukim.edu.mk

Lidija Kapuševska-Drakulevska

Ss. Cyril and Methodius University, Skopje

1.drakulevska@flf.ukim.edu.mk

Во својата култна, сега веќе класична книга „1984“, Џорџ Орвел опишува машина за сецкање, која треба да ги уништи сите неподобни сеќавања. Оваа застрашувачка фикционална (утописка) визија не е многу далеку од историската вистина на нашето совремие; живееме во дигитална доба кога меморијата, како никогаш досега, најмасовно се изделува од нас и продолжува да йроиекувва некако сосема независно од нас. За жал, органичката меморија, која се потпира врз природните човечки способности: психолошки, интелектуални, телесни итн., сѐ повеќе се повлекува на маргините и изгледа како излишна, анахрона постапка во споредба со суверената моќ на електронските медиуми. А „човекот, всушност е човек само тогаш кога се сеќава“ - гласи варијацијата на една позната Шилерова 
изрека, или „човечките суштества се благословени со моќта на паметењето“ - запишал Вистан Хју Одн.

Во услови кога е евидентно загрозена „емоционалната меморија“ како супститут на човековиот субјективитет и идентитет, Филолошкиот факултет „Блаже Конески“ - Скопје е една од малобројните институции кои се обидуваат да ја негуваат уметноста на меморијата преку јазикот и писмото. Зборникот на трудови од третата студентска филолошка конференција „Како си ми?“ (2017), е убава потврда за тоа. Оваа конференција веќе има тригодишна традиција зад себе и полека го испишува својот историјат. Студентскиот организациски тим на четвртата студентска филолошка конференција „Како си ми?“ за 2018 година е воедно и Редакциски одбор на Зборникот од 2017 г. и него го сочинуваат студентите: Викторија Блажеска, Мања Величковска, Ведран Диздаревиќ, Сашка Грујоска и Методи Ефремов.

Како да се спои теоријата со практиката?! Како теориското знаење да добие своја практична примена?! Вечна дилема на науката, особено на филологијата, со оглед на нејзиниот неегзактен карактер. Во филологијата два и два никогаш не се четири. Но, токму во непредвидливоста на филолошката наука лежи нејзината предност, привлечност, провокативност.

Вистинска среќa е да се работи со млади и креативни луѓе. Уште поголема среќa е да се види дека чудесната симбиоза на знаењето и талентот на тие млади луѓе, резултира со конкретно дело - зборникот на трудови содржи 12 труда од вкупно 15 колеги, сите студенти на Филолошкиот факултет „Блаже Конески“ од Скопје, освен двајца, од кои едниот е од ФЕИТ-Скопје, а вториот, од Педагошкиот факултет од Битола.

Вавилонското шаренило од гласови што го детерминира нашиот факултет како дом на јазиците, литературите и културите, доаѓa до израз преку текстовите во зборникот кои третираат теми од доменот на: англистиката, германистиката, италијанистиката, компаратистиката, интермедијалните и традуктолошките студии, но и од доменот на лингвистиката и дидактиката општо. Сите научни трудови се одликуваат со акрибичност, аналитичност, систематичност, висок степен на култура на изразот; трудовите се придружени со релевантна цитирана литература, најчесто од странски автори. За поздравување е критичкиот дух, кој провејува низ херменевтичките анализи, што е за поздравување кај младите научници застапени во зборникот на трудови од третата студентска филолошка конференција „Како си ми?“, кои речиси воопшто и да не им робуваат на авторитетите, туку умеат аргументирано да ги изнесат своите лични ставови и оригинални погледи. За еден ваков исход, во голема мера придонесува, веројатно, не само фактот дека слободната критичка мисла им е природно својствена на младите туку и плодотворната интеракција со професоритерецензенти на застапените трудови: Рајна Кошка, Елизабета Шелева, Зорица Николовска, Симон Саздов, Владимир Мартиновски, Марија ЃорѓиеваДимова, Румена Бужаровска, Милан Дамјаноски, Калина Малеска-Гегај, Марија Паунова, Елена Ончевска-Агер и Ирина Талевска. Лектори на 
трудовите, се исто така, научни дејци од редот на вработените на Факултетот: Томислав Треневски, Марија Паунова, Бојан Петревски и Андријана Павлова.

Во обид за типологизација на застапените текстови во зборникот, истите се групирани во неколку посебни области, според тематолошкиот принцип:

Иниеермеgијално иромислување на книжевнииее феномени е присутно во текстот на Викторија Блажеска за кралот на вилите од Гете до Рамштајн и во заедничкиот труд на Марија Воданова и Марија Ангеловска, посветен на Шекспир во музиката и во филмот. Акцентот е ставен на трансферот на уметничкото дело од еден во друг медиум, што претставува вонреден пример за метаморфозата како настан сам по себе, бидејќи на едно дело, кое со подеднаков успех минува низ неколку различни уметнички медиуми, му претходи, а од него и произлегува, цел синџир на преобразби. Притоа, клучна е релацијата хипотекст-хипертекст, според терминологијата на Жерар Женет. Не ретко, трансферот се реализира од елитната кон популарната култура, и на тој начин се врши актуализација на некои класични уметнички остварувања, од типот на Гете или на Шекспир, како во конкретните две истражувања.

Следна тематска целина чинат трудовите на Фросина Крушкаровска за

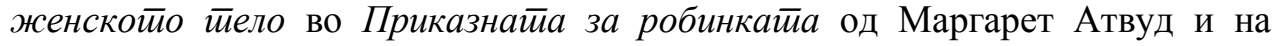
Моника Стојановска за женскойо иичсмо во романот Жена на Сибила Алерамо. Дали е потребно да се биде жена за да се говори како жена? Оваа дилема своевремено поставена од Шошана Фелман, една од застапничките на феминистичката критика, е клучна за анализите во споменатите текстови. Женскиот глас е глас на Другиот, маргинализираниот, субверзивниот субјект, со еден збор, контракултурен ентитет.

На истата линија функционира и суптилната проблематика поврзана со

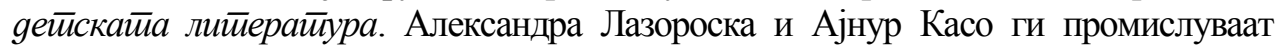
детските ликови во неколку раскази на Селинџер, а Мартина Јанеска ги изнесува аргументите „pro et contra“ на американската критика за „расизмот“, односно за „антирасизмот“ на култната детска книга Хаклбери Фин од Марк Твен. Етикетирањето, стигматизирањето на детската литература е многу опасно и наместо цензура, младите умови треба да имаат шанса да научат да мислат критички и самите да формираат мислења преку аргументирано соочување на сопоставените ставови - со право констатира Мартина Јанеска.

Со мошне остроумни крийички согллеgби се одликува визурата на Ведран Диздаревиќ на Милан Кундера како теоретичар на романот. Кундера, според авторот на овој труд, теориски - во своите есеи, но и практично - во сопствените романи, му наметнува голема одговорност на романот како форма. Оттаму и заблудата да го третираме Кундера како автор на филозофски роман: „Посочивме уште на почетокот дека романот се истакнува токму таму каде што науката и филозофијата потфрлиле“- пишува Диздаревиќ и продолжува: „Во таа смисла, вистинскиот роман по самата своја суштина е мисловен, но, не филозофски туку романескен, следејќи ја примарната задача и суштината на духот на романот, а тоа е, секако, истражувањето на заборавените или скриените аспекти на битието“. 


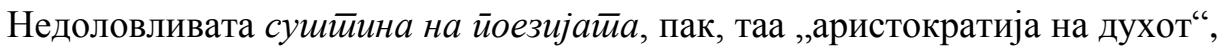
како што ја нарекува Данило Киш, нејзината божественост или магија, е тематизирана во текстот на Мања Величковска, која го фокусира својот интерес кон постпоезијата на Лидија Димковска и на Методиј Златанов. Што е тоа постпоезија? Кои се нејзините одлики? И во каква релација е таа со постмодерната? Постпоезијата, според авторката, бележи исклучителна свест (и метатеориска самосвест) и мултимедијално ја проблематизира стварноста, позајмувајќи алатки од другите медиуми, каде што истовремено владее современиот закон за поливалентност. Таа е млада „уметничка гранка“, која се издвојува со својата горделивост и самоироничност и подразбира повеќедимензионални лирски субјекти. Очудената семантика на домот, бездомноста, невдоменоста, номадизмот, миграцијата и егзилот се заеднички теми во творештвото на Димковска и Златанов, но и есенцијални проблеми за постпоезијата воопшто.

Исток Улчар прави компаративна анализа на три йреиеви на култната песна на Ален Гинзберг „Виј/Рев“ на македонски јазик и тоа од страна на Саво Цветановски, Богомил Ѓузел и Зоран Анчевски. Интересно е што, според авторот, ниту еден препев не е идеален, па критички промислувајќи ги, тој, за секој одделен аспект се приклонува кон едно препејувачко решение, без пристрасност или субјективност во изборот. Препевот како метакреација, варијациите на препевот и задачата на препејувачот (Валтер Бењамин) е клучната аријаднина нишка, според Улчар, која води до успешно реализиран трансфер на едно уметничко дело од еден во друг јазичен систем.

Во доменот на јазичнио $\bar{u}$ асиекей во третманот на одбраната тема, влегуваат трудовите на Дејан Пејовски, кој пишува за електротехниката во разговорниот јазик и заедничкиот труд на Христина Видевска и Елена Стојковска за јазичното влијание од српскиот јазик во лексиката и во синтаксата на македонскиот јазик. Целта на првиот споменат труд е да се посочат примери од разговорниот јазик во кои се забележува разлика помеѓу вообичаената секојдневна употреба на термини од областа на електротехниката, од една страна, и научното восприемање, од друга. Текстот е извонредно луциден и особено интересен и за филолозите, исто така, бидејќ у упатува на разграничување на изразите: „плаќам сметка за струја“ наспроти „сметка за енергија“, или „денеска два часа немаше струја“ наспроти „немаше напон“, како и на очигледните разлики помеѓу „сијалица“ и „светилка“. Во текстот кој го третира влијанието на српскиот на македонскиот јазик, се анализираат грешките што се провлекуваат, не само во разговорниот стил, туку и во другите функционални стилови. Акцентот е ставен на јазичните грешки коишто се застапени во секојдневната јазична комуникација, поради фактот дека говорителите на македонскиот јазик, поради блискоста со српскиот јазик, не се доволно запознаени за низата некоректности што ги употребуваат, мислејќи дека се дел од нашиот јазичен стандард. 
Кога станува збор за насйавайа йо сиирански јазик, треба да се истакне дека методиката и дидактиката, како и практичната настава, претставуваат клуч за успешен и креативен образовен процес, кој во својот центар ги става учениците/студентите како субјекти. Со критички согледби во име на поквалитетна настава, а за поголема стимулација и мотивација на студентите, во својот труд се залага Лилјана Белакапоска. Во трудот се презентирани мислења на студентите по англиски јазик од завршните години на студии во врска со евентуалните тешкотии при планирањето на наставата кои ги очекуваат по првото вработување. Во теоретскиот дел од трудот се елаборирани дидактичките основи на планирањето на наставата и застапеноста на педагошките компоненти во студиските програми за образование на наставници по англиски јазик во Република Македонија. Во емпирискиот дел на истражувањето се презентирани методологијата и резултатите од анкетирањето на студентите. Резултатите покажуваат мала застапеност на педагошките дисциплини и различен вид на потенцијални проблеми од дидактичка природа со кои студентите очекуваат да се соочат при своето прво вработување.

Зборникот од третата студентска филолошка конференција „Како си ми?“ претставува значајно теориско-аналитичко остварување кое, несомнено, ќе биде неодминливо четиво во иднина за сите оние кои се занимаваат со филолошките науки. Овој зборник промовира еден интеркултурен дијалог или „свет во светот“, во духот на традицијата на Филолошкиот факултет „Блаже Конески“ - Скопје. Иднината, несомнено, им припаѓа на младите; без нив, ние, повозрасните, би биле само едно „закрпено палто на стап што виси“, како што вели В. Б. Јејтс во својата култна песна „Едрење кон Византија“. Во оваа смисла, нашите драги идни филолози се наша гордост и ним им останува одговорноста да ја продолжат благородната мисија на изучување на странските јазици, литератури и култури, бидејќи запознавањето на Другиот значи и себеспознавање. 